\title{
Major magmatic events in Mt Meredith, Prince Charles Mountains: First evidence for early Palaeozoic syntectonic granites
}

\author{
N. A. Gongurov, ${ }^{1}$ A. A. Laiba, ${ }^{1}$ and B. V. Beliatsky ${ }^{2}$ \\ ${ }^{1}$ PMGRE, 24, Pobeda St., Lomonosov, 189510, Russia \\ ${ }^{2}$ VNIIOkeangeologia; 1, Angliysky Ave., 190121, St.-Petersburg, Russia
}

\begin{abstract}
Precambrian rocks at Mt Meredith underwent granulite-facies metamorphism $\mathrm{M}_{1}$. Zircon isotope dating for two orthogneisses revealed the following age signatures: $1294 \pm 3$ and $957 \pm 4 \mathrm{Ma} ; 1105 \pm 5$ and $887 \pm 2 \mathrm{Ma}$. The oldest ages could reflect the time of orthogneiss protolith crystallization and the latest age determinations date Grenvillian metamorphism. The metamorphic rocks were intruded by two-mica and garnet-biotite granites. The granites and host rocks underwent amphibolite-facies metamorphism $\mathrm{M}_{2}$. Zircon isotope analysis of the two-mica granites showed age estimation within $550-510 \mathrm{Ma}$ and zircon dating of the garnet-biotite granites revealed the ages of $1107 \pm 5,953 \pm 8$, and $551 \pm 4 \mathrm{Ma}$. As Pan-African age signatures were obtained from only the granite samples, it is possible to suggest that the granites were formed at the time of 510-550Ma and the zircons with greater age values were captured by granites from the host rocks.
\end{abstract}

Citation: Gongurov, N.A., A.A. Laiba and B.V. Beliatsky (2007), Major magmatic events in Mt Meredith, Prince Charles Mountains: First evidence for early Palaeozoic syntectonic granites. in Antarctica: A Keystone in a Changing World - Online Proceedings of the $10^{\text {th }}$ ISAES, edited by A.K. Cooper and C.R. Raymond et al., USGS Open-File Report 2007-1047, Short Research Paper 100, 4 p.; doi:10.3133/of2007-1047.srp100.

\section{Introduction}

Mt Meredith is situated in the central part of the Prince Charles Mountains $\left(71^{\circ} 11^{\prime} \mathrm{S}, 67^{\circ} 43^{\prime} \mathrm{E}\right)$. It is part of Middle-Late Proterozoic mobile belt known as the Circum-Polar or Wegener-Mawson belt.

First investigations of the Mt Meredith were carried out by Soviet and Australian geologists in the 19701980s. In 1991 Australian geologists visited Mt Meredith for the second time. By microprobe U-Pb zircon dating they discovered in paragneisses inherited zircons of Archaean and Proterozoic ages of 2800-2500 and 2100$1800 \mathrm{Ma}$, respectively (Kinny et al., 1997). Russian geologists investigated Mt Meredith during the field seasons of 2004 and 2006 (49-th and 51-st RAE) with the aim to study in detail the geological structure of the massif in order to determine the geologic structure of the region. The present paper presents the results of these investigations.

Mt Meredith is made up of Precambrian metamorphic rocks, which strike north-east $\left(10^{\circ}-65^{\circ} \mathrm{NE}\right)$ and dip to the north-west $25^{\circ}-70^{\circ}$. Within the metamorphic complex there are layers of Palaeo-Mesoproterozoic (?) metasedimentary and Mesoproterozoic metaintrusive rocks. Metasedimentary rocks include biotite-plagioclase paragneiss, garnet-biotite paragneiss, quartzites, marbles and calc-silicates; metaintrusive rocks are represented by biotite-amphibole-plagioclase (metadiorites), biotite-amphibole orthogneisses (metagranitoids), biotite-amphibole-plagioclase and pyroxene-amphibole-plagioclase metabasites. Metamorphic rocks contain sub-conconcordant bodies and veins of metamorphosed Early Palaeozoic granitoids. The youngest intrusive rocks are dykes of alkaline picrites of Cretaceous age, discovered in the south-western part of Mt Meredith (Fig. 1) (Laiba et al., 2006).

\section{Early Palaeozoic syntectonic granites}

According to chemical composition and spatial relationships, the granites are divided into two groups: a) two-mica and biotite granites ("Pink" granites); b) garnetbiotite granites and leucogranites ("White" granites).

"Pink" granites occur in the southern part of the massif. They make up a large sub-conformal body with north-east strike, thickness about $600 \mathrm{~m}$ and not less than $10 \mathrm{~km}$ long. Close to the main body there are numerous veins $1-25 \mathrm{~m}$ thick with north-east strike $\left(10^{\circ}-30^{\circ} \mathrm{NE}\right)$ and westerly dips $40^{\circ}-50^{\circ}$. As a rule, the granite veins are concordant or sub-concordant with the host rocks metamorphic fabric, but in some cases they cut the host rocks which occur as xenoliths. Pink granites are characterized by heterogeneous structure - from pegmatoid to fine-, medium-grained; their texture are granite, blastogranite and blastoclastic.

"White" granites crop out in the central and northern parts of Mt Meredith. They form large concordant bodies with north-east strike. These granites contain partially contaminated layers of different gneisses, quartzites and metabasites. White granites occur, at least, in two generations. Granites of the first generation inject sub conformably the gneisses forming granite-gneiss stratified layers. They are clearly gneissic coarse-grained or pegmatoid rocks with considerable variation in proportion and amount of dark-colored minerals $(\mathrm{M}=1-15)$. Granites of the first generation are cut by granites of the second generation. Late granites are fine- or medium grained, massive or weakly schistose rocks. Dark colored minerals are represented by garnet and biotite $(\mathrm{M}=10-15)$. Fine grained biotite and garnet often form round aggregates with diameter from $2-3$ to $10 \mathrm{~mm}$ giving the granites a spotty structure. 


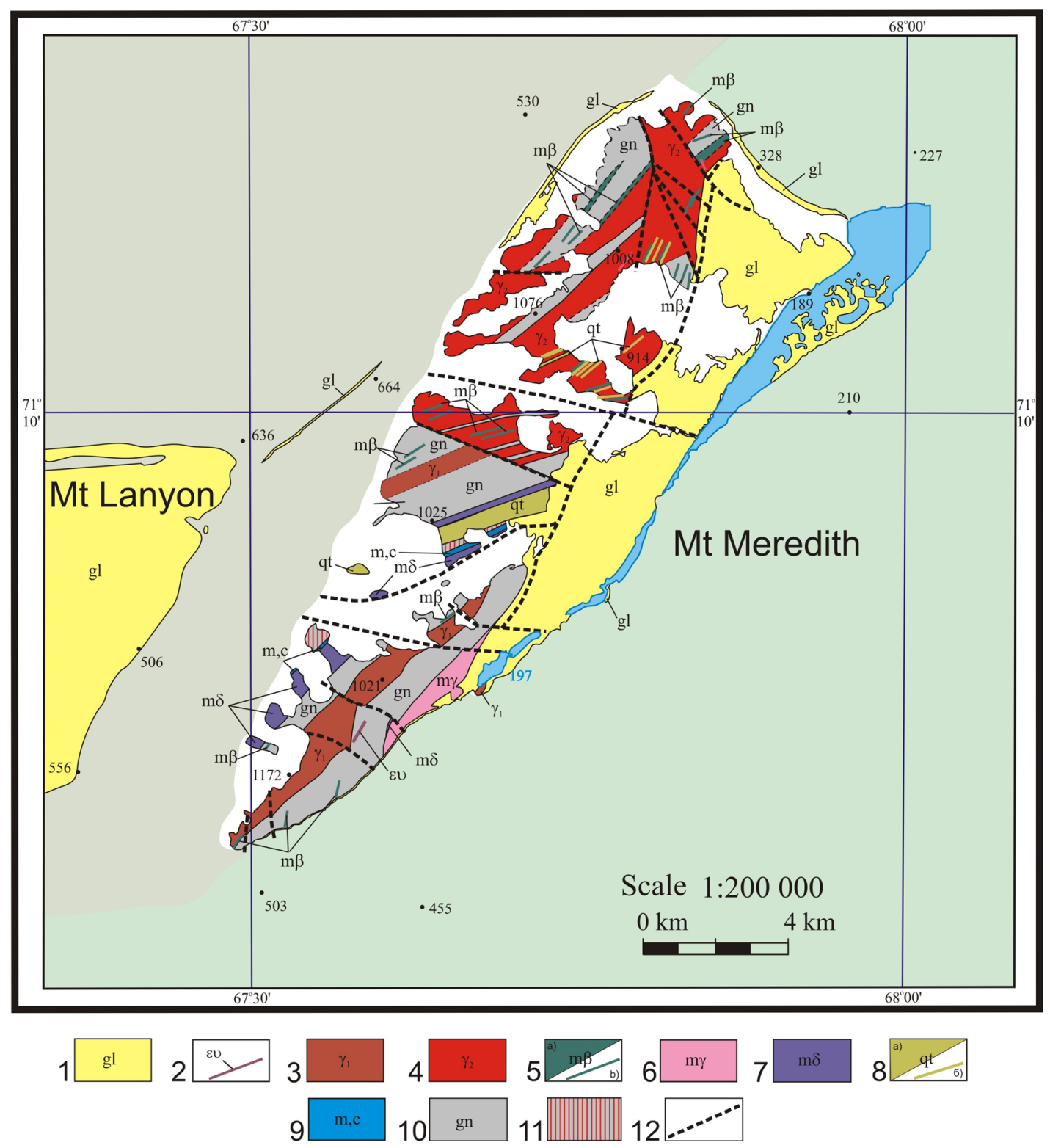

Figure 1 Geological sketch map of Mt Meredith. 1-Cenozoic sediments; 2-Cretaceous flogopite alkaline picrite dyke; 3-Early Palaeozoic "Pink" Ms-Bt granite; 4-Early Palaeozoic "White" Gr-Bt granite; Mesoproterozoic metaintrusive rocks (5-7): a) units, b) layer-shaped bodies; 6-Bt-Am orthoneisses (metagranitoids); 7-Bt-Am-Pl orthogneisses (metadiorites); Palaeo-Mesoproterozoic (?) metasedimentary rocks (8-10): 8-quartzite: a) units, b) layer-shaped bodies; 9-marble, calc-silicates; 10-paragneisses; 11-zone strongly migmatised rocks; 12 -inferred faults

In general, according to the mode of occurrence of the granites, it is possible to suggest that they were intruded syntectonically.

"Pink" granites have equal amounts of plagioclase and microcline $(30-40 \%)$, in "White" granites microcline prevails over plagioclase (50-55 \% and 15-30\%, respectively). Biotite and muscovite are typical for the "Pink" granites (1-2\%), garnet grains are less common. In the "White" granites there is from $2-3 \%$ to $10 \%$ of biotite and about $1-3 \%$ of garnet, the latter occurs in the form of round grains about $1 \mathrm{~mm}$ in diameter or in the form of disintegrated crystals, sometimes, strongly corroded by quartz. Accessory minerals of the "Pink" granites are represented by monazite, zircon, magnetite, ilmenite, apatite, whereas in the "White" granites there are only zircon and, rarely, apatite. Secondary alterations are observed in the form of sericite after plagioclase and chlorite after biotite.

Chemical compositions of the granites are practically similar. In the total alkaline - silica diagram the compositions of both granite groups plot in the fields of leucogranites, sub-alkaline and alkaline leucogranites. 
$\mathrm{SiO}_{2}$ content varies within $70-77.5 \%, \mathrm{~K}_{2} \mathrm{O}-3-6 \%, \mathrm{Na}_{2} \mathrm{O}$ $-2.5-4.5 \%$. Index of $\mathrm{mg}$ (atomic $100 \mathrm{Mg} /\left(\mathrm{Mg}+\mathrm{Fe}^{2+}\right)$ ) varies considerably from 12.3 to 46 for the "Pink" granites and from 9.4 to 53.3 for the "White" granites. The granites are characterized by low $\mathrm{Nb}(2-25 \mathrm{ppm})$ and Y (6-60 ppm) contents and moderate Rb (100-300 ppm) content. Index ASI for the majority of rocks is within the limits of $1.05-1.15$. The relation $\mathrm{Ba} / \mathrm{Rb}$ is mainly within the limits of $0.8-6.2, \mathrm{~K} / \mathrm{Rb}-150-300$. At the same time, parameters $\mathrm{Fe}^{*}=\mathrm{Fe}_{2} \mathrm{O}_{3}{ }^{\text {tot }} /\left(\mathrm{Fe}_{2} \mathrm{O}_{3}{ }^{\text {tot }}+\mathrm{MgO}\right)$ (wt \%) and $\mathrm{MALI}=\mathrm{Na}_{2} \mathrm{O}+\mathrm{K}_{2} \mathrm{O}-\mathrm{CaO}$ (wt \%) (Frost et al., 2001) vary over a wide range (0.6-0.9 and 3-9, accordingly). "Pink" granites correspond with Ferroan type, and "White" granites as Ferroan, and Magnesian types. Also both types granites cover a wide number of compositions from calcic
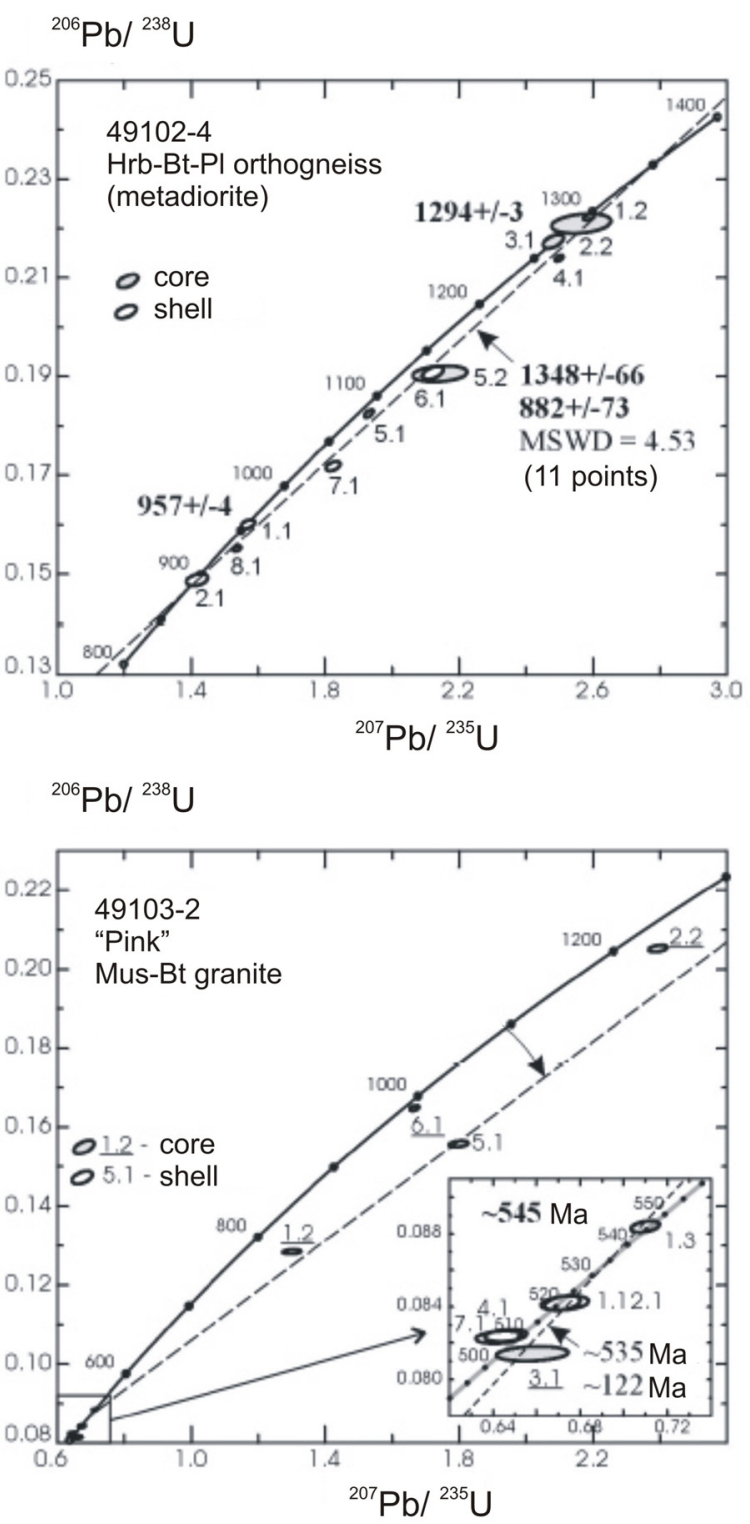

to alkali-calcic type (Frost et al., 2001). Similar variations of compositions are characteristic for peraluminous leucogranites.

\section{Isotope dating}

Four rock samples from Mt Meredith were dated by zircon U-Pb microprobe analysis (SHRIMP-II). The measurements were performed at the Isotope Centre of VSEGEI (St-Petersburg, Russia). Orthogneiss sample 49102-4 showed the most concordant age data (Fig.2) $1294 \pm 3$ and $957 \pm 4 \mathrm{Ma}$; another orthogneiss sample 49111-8 revealed concordant age data of $1105 \pm 5$ and $887 \pm 2 \mathrm{Ma}$. The oldest ages could reflect the time of crystallization of the orthogneiss protolith, the latest data
${ }^{206} \mathrm{~Pb} /{ }^{238} \mathrm{U}$
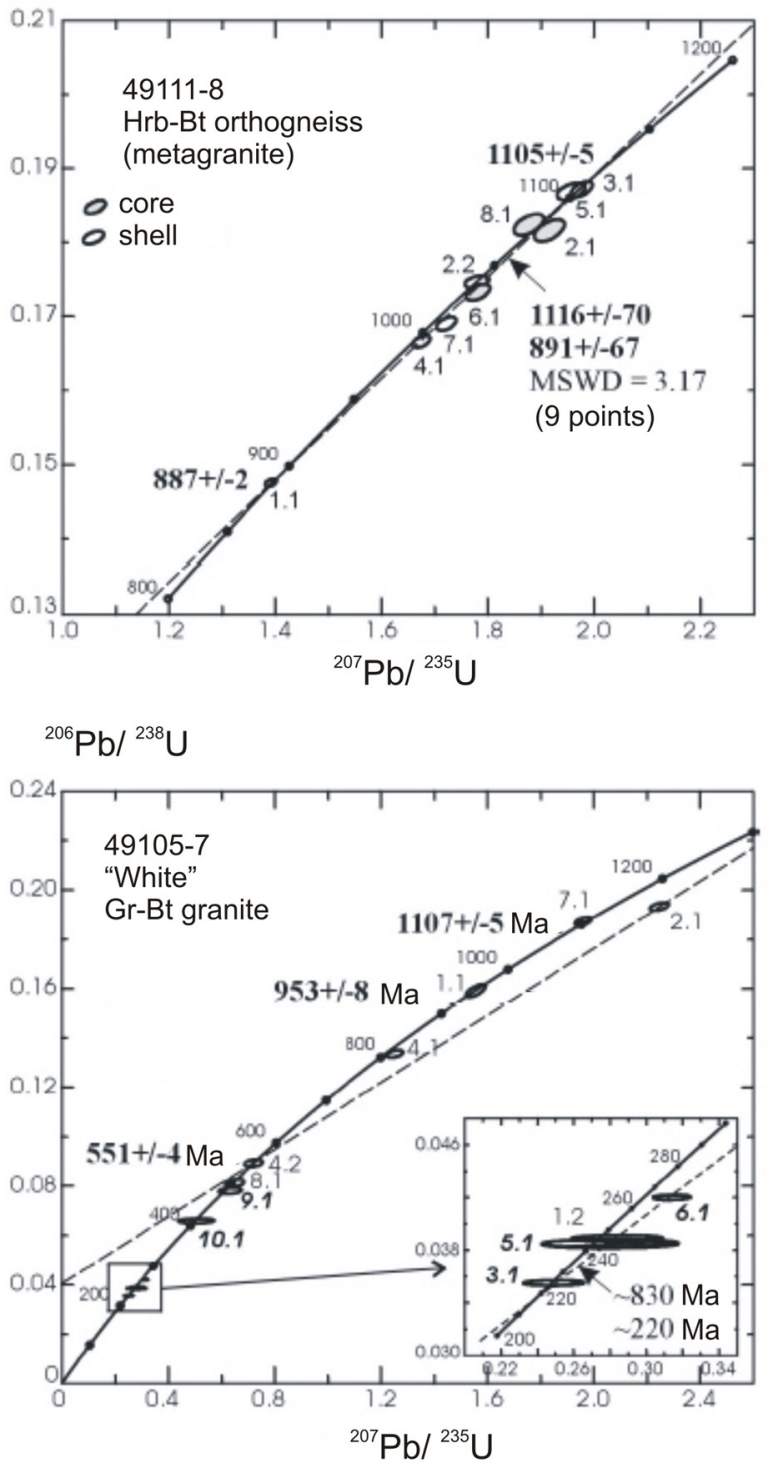

Figure 2. $\mathrm{U}-\mathrm{Pb}$ isotopic diagrams for zircons from $\mathrm{Mt}$ Meredith rocks. 
could correspond to the phases of Grenvillian metamorphism.

Zircons from the "Pink" granites (sample 49103-2) are fine $<0.085 \mathrm{~mm}$. The grains are prism shaped with a primitive facet. 10 analyses on 7 grains from this sample were carried out. Cathode-luminescent images clearly show internal heterogeneity of grains with development of a separate core and surrounding shell. Cores and shells show a comparable range of $\mathrm{U}$ (1500-2800 ppm) and Th $(40-520 \mathrm{ppm})$. Th/U ratio is without exception in the range $0.03-0.12$ both for internal zones, and for areas that suggest a metamorphic origin or intensive processing of this population of zircon. Therefore cores are unlikely to retain the primary isotope characteristics.

Six analyses have low values of model ${ }^{206} \mathrm{~Pb} /{ }^{238} \mathrm{U}$ age in a range 550-510 Ma (five of them are from hypothetical shells). These analyses are almost concordant. The others 4 analyses are considerably unconcordant with values of model ${ }^{206} \mathrm{~Pb} /{ }^{238} \mathrm{U}$ age in the range 1200-1800 $\mathrm{Ma}$ (three analyses are from hypothetical cores of grains). Thus, the isotope data on this sample testify to crystallization of the granite in the range 550-510 Ma. The most probable estimation of age is $546 \pm 2 \mathrm{Ma}$, which relates to concordant analysis 1.3 (Fig. 2).

Zircons from the "White" granite (sample 49105-7) are two populations of well faceted grains: short-prism $(1=1.5-2.2)$ and long-prism $(1=3.0-6.0)$ grains. Cathodeluminescent images do not show precise cores and shells. 12 isotope analyses on 10 grains were undertaken. $U$ and Th vary over a wide range: $220-7800 \mathrm{ppm}$ and 60-4100 ppm respectively.. The $\mathrm{Th} / \mathrm{U}$ ratios are high and within the range of $0.1-0.8$, which suggests a magmatic origin of this population. Zircons for the "White" granite resulted in concordant age data $1107 \pm 5,953 \pm 8$ and $551 \pm 4$ Ma. As the youngest ages (Pan-African) are obtained only for the zircons from the granites, it is possible to suggest that the granites themselves were formed during the period of 510-551 Ma, and the zircons of older age were captured by the granites from the host rocks.

\section{Discussion}

Structural, petrographic and isotope data from $\mathrm{Mt}$ Meredith have revealed three stages of ductile deformations and three stages of metamorphism.

$\mathrm{D}_{1}$ was synchronous with the initial phase of regional metamorphism when the gneissic layering formed under conditions of simple shear. The schistocity S1 is axial planar to intrafolial folds. Measured joints and axial fold planes dip in the north-west direction with small angles. At $\mathrm{D}_{3}$ stage the rocks of Mt Meredith were deformed into folds of different scale. There are small folds $\mathrm{F}_{2} \quad 0.2-2 \mathrm{~m}$ in size and larger ones - with the height up to $50-100 \mathrm{~m}$ and width 25-50 $\mathrm{m}$ which deform the gneiss layers. Axial fold planes dip to the north-east at an angle of $45^{\circ}-55^{\circ}$. Measured fold joints dip to the south-west $\left(250^{\circ} \mathrm{SW}\right)$ and north-east $\left(35^{\circ}-70^{\circ} \mathrm{NE}\right) . \mathrm{D}_{1}$ and $\mathrm{D}_{2}$ stages are connected with the first stage of metamorphism $\mathrm{M}_{1}$, which took place under conditions of granulite facies, based on the discovered relics of orthopyroxene. For the northern part of the Prince Charles Mountains similar fold structures are described as a metamorphic event of Grenville age (Boger et al., 2001), so the $\mathrm{D}_{1}$ and $\mathrm{D}_{2}$ stages at $\mathrm{Mt}$ Meredith could correspond to this event. The obtained age data for the orthogneisses also support this view.

$\mathrm{D}_{3}$ stage is recognized as shear zones (1-5 cm thick) which are found in metabasites and gneisses of different composition. Granite veins by both deformed by the shear-zones and intrude along the shear zones. Dislocations along the zones have different character with amplitude of not more than $10 \mathrm{~cm} . \mathrm{M}_{2}$ stage is connected with $\mathrm{D}_{3}$ which corresponds to conditions of high temperature amphibolite-facies.

Mineral associations of regressive metamorphism of $\mathrm{M}_{3}$ stage with conditions corresponding to green-schist facies are found in all metamorphic rocks and in the granites. It is connected with brittle deformation which divided the massif into separate tectonic blocks.

\section{Conclusions}

The age data obtained from granites in the central part of the Prince Charles Mountains suggest for the first time that the granites are part of an Early Paleozoic tectonicthermal event. The presence of metamorphic layering in the granites, elements of late folding and particular mineral associations prove that the granites underwent deformations of $\mathrm{D}_{3}$ stage, late amphibolite and then green-schist metamorphism.

The Early Paleozoic granites of Mt Meredith have similar chemical characteristics to Pan-African granites of the Mawson Escarpment and in the Prydz Bay area.

Acknowledgments We thank E. V. Mikhalsky and Bryan C. Storey for the careful review of the manuscript.

\section{References}

Boger S. D., C. J. L. Wilson, and C. M. Fanning (2001), Early Palaeozoic tectonism within the East Antarctic Craton: The final suture between east and west Gondwana?, Geology, 29, 463-466.

Frost B. R., C. G. Barnes, W. J. Collins, R. J. Arcullus, D. J. Ellis, and C. D. Frost (2001), A geochemical classification for granitic rocks, Journal of Petrology, 42, 2033-2048.

Laiba A. A., N. A. Gongurov and I. V. Kudriavtsev (2006), Geological observations on Mt. Meredith (Prince Charles Mountains) during the 49-th Russian Antarctic Expedition, Russian Earth Science Research in Antarctica, 1, 9-32 (in Russian).

Mikhalsky E. V., A. A. Laiba and B. V. Beliatsky (2006), Age and compositional features of rocks from Mt. Meredith and the eastern fringe of the Amery Ice Shelf, Russian Earth Science Research in Antarctica, 1, 66-93 (in Russian).

Kinny P. D., L. P. Black and J.W. Sheraton (1997), Zircon U-Pb ages and geochemistry of igneous and metamorphic rock in the northern Prince Charles Mountains, Antarctica, AGSO Journal of Australian Geology \& Geophysics, 16 (5), 637-654. 